\title{
Elderly Psychological Conditions in the Nursing Home Tresna Werdha (Pstw): A Study Descriptive Riau and West Sumatra Indonesia
}

\author{
Nurvi Susanti* (iD, Zulfan Saam, Nofrizal Nofrizal (iD, Zahtamal Tamal(D, Nofri Hasrianto (D) \\ Doctoral Program Environmental Science, University of Riau, Pekanbaru, Indonesia
}

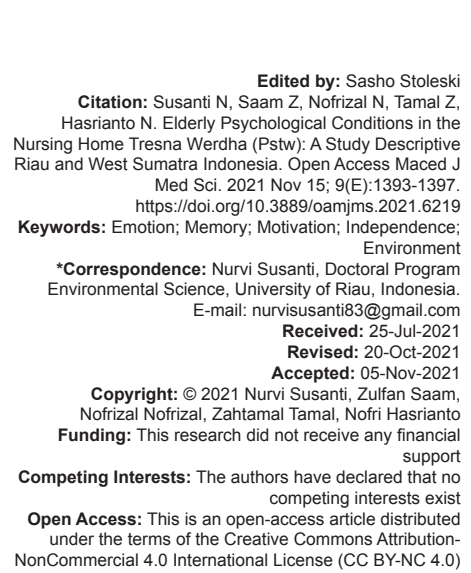

Introduction

Getting older is a process that is often experienced by humans who have gotten older, but it is something that is normal for the elderly to experience. Where everyone hopes that in carrying out the elderly, they want to live a quiet, peaceful and loving life with their children, grandchildren, and family. In this condition, the elderly carry out the fulfillment of their physical, biological, psychological, social, and economic conditions. Based on the above problems, efforts are needed to overcome new problems for the elderly and the community can be resolved properly [1].

Data obtained by the Ministry of Health 2020, the number of elderly people in Indonesia continues to increase every year, by 25.9 million people $(9.7 \%)$ in 2019 to 27.1 million people in 2020 , and it is predicted that in 2035 it will continue to increase 48.2 million people (15.8\%). Riau Province currently has 11,217 elderly people in 2019. Meanwhile, West Sumatra Province in the same year has 17,948 elderly people [2]. Based on these criteria, age continues to increase the life expectancy of the elderly. That the conditions in their field are often neglected, even being put into nursing homes by their families. Therefore, the important role of the nursing home as a place for care and care for the elderly is needed [3].

A nursing home is a house or place (residence) that accommodates, cares for or a gathering place for elderly people, either voluntarily or submitted by the family to be taken care of all their needs, equipped with adequate facilities and infrastructure, service schedules, and adequate services for elderly [4], [5]. The quality of life of the elderly is influenced by various factors such as physical health, social, and environmental relationships from psychological [6]. Psychological conditions that are often experienced by the elderly include aspects of emotion, memory, motivation, and independence [7].

The purpose of this study was to analyze the psychological health conditions of the elderly consisting of aspects of emotion, memory, motivation, and independence [8] in the nursing homes of Husnul Khotimah Pekanbaru and Sabai Nan Aluih Pariaman. 


\section{Methods}

This type of research is a descriptive survey. The subjects in this study amounted to 35 elderly people in the Husnul Khotimah nursing home, Pekanbaru, and 45 elderly people in the Sabai Nan Aluih Pariaman nursing home with a total sampling technique. Data collection is taken using a questionnaire containing emotional variables with good categories if $68-100 \%$, moderate if $34-67 \%$, and less if $0-33 \%$; memory variable is in good category if $68-100 \%$, moderate if $34-67 \%$, and less if $0-33 \%$; good motivation variable if $68-100 \%$, moderate if $34-67 \%$, and less if $0-33 \%$; and independence variable in good category if $68-100 \%$, moderate if $34-67 \%$, and less if $0-33 \%$. The data were collected descriptively by presenting a description of each variable presented in the two nursing homes studied.

\section{Results}

Emotional aspects which compare emotional aspects between two nursing homes are presented in Figures 1 and 2. Emotion aspects included annoyance, sickness, happy activities, happy to interact, sad for the family to come home, talking, fear of dark, and sleeping difficulty were categorized into good category if $68-100 \%$, moderate if $34-67 \%$, and less if $0-33 \%$.

Based on the data from Table 1, out of 35 respondents in Husnul Khotimah nursing home, giving the answer for question 2 in the category of moderate (they feel the sickness when the manager always dictates) have the highest value of $69 \%$ with good criteria in emotional aspects; while out of the 45 respondents in Sabai Nan Aluih Pariaman, giving the answer for question 4 is in good category (likes to interact with others) have the highest value $73 \%$ with good criteria in emotional aspects.

The memories aspects included remembering prayers, remembering eating, remembering hours, forgetting something, remembering friends' names, remembering experiences, remembering children's names, remembering family names, remembering years of birth, remembering years of children's birth, remembering birth of husbands, remembering births of wives, remembering those who led to the orphanage were categorized into good categories if $68-100 \%$, moderate if $34-67 \%$, and less if $0-33 \%$.

Based on the data from Table 2, out of 35 respondents in Husnul Khotimah nursing home, giving the answer for question 3 was in good category (remembering hours) have the highest value as much as $80 \%$ with good criteria in memories aspects; while out of 45 respondents in Sabai Nan Aluih Pariaman, giving the answer for question 2 was in good category (remembering eating) have the highest value of $69 \%$ equal to good criteria in memories aspects.

Motivation aspects included health checks, not taking medication, not needing family visits, indifference, reading, spirituality, sports, skills, and watching TV; categorized into good categories if $68-100 \%$, moderate if $34-67 \%$, and less if $0-33 \%$.

Based on the data from Table 3, out of 35 respondents in Husnul Khotimah nursing home, giving answer to question 4 is in the category of very bad (managers and families are indifferent to elderly conditions) with the highest value of $51 \%$ with moderate criteria in motivation aspects; while out of 45 respondents in Sabai Nan Aluih nursing home, giving the answer for question 6 in moderate category (must remember spiritually every day) which having the highest value as much as $51 \%$ with moderate criteria in motivation aspects.

Independence aspects include lavatory, taking medicines, conflicts, completing tasks, helping friends, putting things in their place, being happy to be involved in group activities, discussing equating perceptions, and assignments given fairly are categorized into good categories if $68-100 \%$, moderate if $34-67 \%$, and less if $0-33 \%$.

Based on the data from Table 4, out of 35 respondents in Husnul Khotimah nursing home, giving the answer for question 8 was in good category (when given the task of discussing and equating perceptions) have the highest value of $80 \%$ with good criteria in independence aspects; while out of 45 respondents Sabai Nan Aluih nursing home, they are giving answer

Table 1: The percentage of emotional aspects of elderly between Husnul Khotimah nursing home and Sabai Nan Aluih nursing home

\begin{tabular}{|c|c|c|c|c|c|c|c|c|c|}
\hline Emotional Aspects & Annoyance & Sickness & Happy Activities & Happy to interact & Sad for the family & Talking to others & Fear of dark & Sleeping difficulty & Average \\
\hline \multicolumn{10}{|c|}{ Husnul Khotimah nursing home } \\
\hline Very good & $3 \%$ & $3 \%$ & $9 \%$ & $20 \%$ & $29 \%$ & $20 \%$ & $6 \%$ & $3 \%$ & $11 \%$ \\
\hline Good & $20 \%$ & $14 \%$ & $34 \%$ & $49 \%$ & $46 \%$ & $29 \%$ & $26 \%$ & $20 \%$ & $30 \%$ \\
\hline Moderate & $51 \%$ & $69 \%$ & $40 \%$ & $20 \%$ & $9 \%$ & $20 \%$ & $20 \%$ & $31 \%$ & $33 \%$ \\
\hline Not good & $3 \%$ & $9 \%$ & $6 \%$ & $0 \%$ & $9 \%$ & $11 \%$ & $29 \%$ & $29 \%$ & $12 \%$ \\
\hline Very not good & $23 \%$ & $6 \%$ & $11 \%$ & $11 \%$ & $9 \%$ & $20 \%$ & $20 \%$ & $17 \%$ & $15 \%$ \\
\hline \multicolumn{10}{|c|}{ Sabai Nan Aluih nursing home } \\
\hline Very good & $2 \%$ & $2 \%$ & $7 \%$ & $9 \%$ & $13 \%$ & $4 \%$ & $4 \%$ & $9 \%$ & $6 \%$ \\
\hline Good & $16 \%$ & $31 \%$ & $64 \%$ & $73 \%$ & $60 \%$ & $53 \%$ & $18 \%$ & $27 \%$ & $43 \%$ \\
\hline Moderate & $49 \%$ & $33 \%$ & $13 \%$ & $13 \%$ & $18 \%$ & $13 \%$ & $20 \%$ & $31 \%$ & $24 \%$ \\
\hline Not good & $16 \%$ & $22 \%$ & $9 \%$ & $2 \%$ & $9 \%$ & $24 \%$ & $56 \%$ & $27 \%$ & $21 \%$ \\
\hline Very not good & $18 \%$ & $11 \%$ & $7 \%$ & $2 \%$ & $0 \%$ & $4 \%$ & $2 \%$ & $7 \%$ & $6 \%$ \\
\hline
\end{tabular}




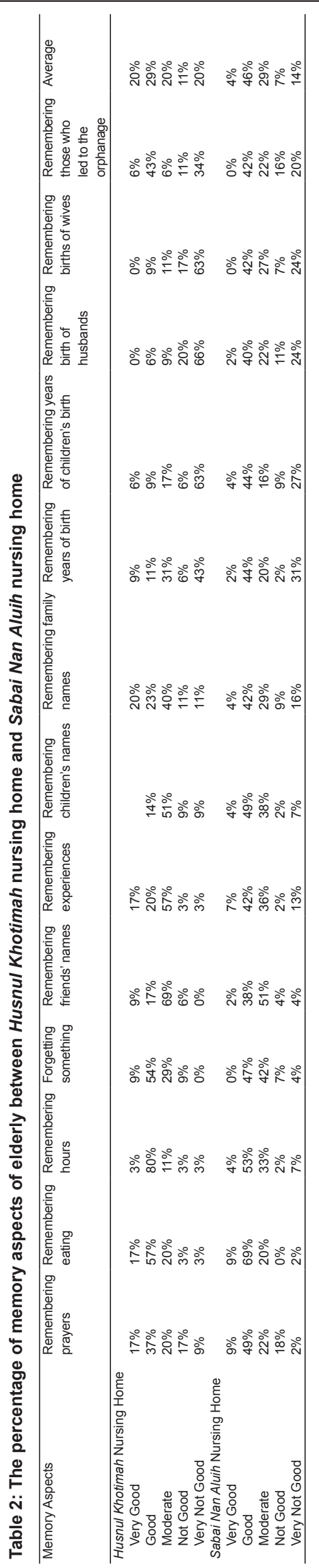

question 7 was good category (happy to be involved in activities at the orphanage) with the highest value of $67 \%$ with moderate criteria in independence aspects.

\section{Discussion}

The discussion on the psychological condition of the elderly from both nursing homes consists of aspects emotion, memory, motivation, and independence.

\section{Aspects of emotion}

- $\quad$ The study of emotions and the elderly shows a negative emotional response in the elderly who experience decreased cognitive and physical abilities. This often causes the elderly to experience stress due to failure to maintain physiological stress conditions [9].

According to the Tentama [10], Herawati [11], elderly is expected to increase positive thoughts to continue the next life well. Positive thinking is the ability to judge things from a positive side so that positive thinking will increase if there is the formation of the ability and habit to judge things from a positive side. The elderly who are in the nursing home by still thinking positively to themselves, others and the environment, the elderly will be able to make good adjustments in the home, the elderly can interact well with other elderly people, and do not distance themselves from new associations at the orphanage of elderly [11].

Based on the researcher's analysis, the emotional level of the elderly in both nursing homes was in the good category because when the elderly felt sick when the manager always reminds the elderly to follow the schedule set by the nursing home such as bath time, eating, doing social activities, and so on. This is due to the fluctuating emotional level of the elderly. Whereas at the Sabai Nan Aluih nursing home the elderly mostly like to act because of their friends to tell stories, both the elderly in one guest house and the elderly at another guest house, who are considered to agree with the elderly to tell stories, complain, joke, and play dominoes for passing togetherness in a nursing home.

\section{Aspects of memory}

Memory is a mental process that includes coding, storing, and recalling information and knowledge, which are all centered in the brain [12]. External stimuli can be in the form 
Table 3: The percentage of motivation aspects of elderly between Husnul Khotimah nursing home and Sabai Nan Aluih nursing home

\begin{tabular}{|c|c|c|c|c|c|c|c|c|c|c|}
\hline Motivation Aspects & Health check & $\begin{array}{l}\text { Not taking } \\
\text { medication }\end{array}$ & $\begin{array}{l}\text { Not needing } \\
\text { family visits }\end{array}$ & Indifference & Reading & Spritualilty & Sports & Skills & Watching TV & Average \\
\hline \multicolumn{11}{|c|}{ Husnul Khotimah Nursing Home } \\
\hline Very Good & $14 \%$ & $9 \%$ & $17 \%$ & $6 \%$ & $9 \%$ & $9 \%$ & $11 \%$ & $3 \%$ & $9 \%$ & $10 \%$ \\
\hline Good & $26 \%$ & $20 \%$ & $9 \%$ & $9 \%$ & $26 \%$ & $40 \%$ & $23 \%$ & $20 \%$ & $20 \%$ & $21 \%$ \\
\hline Moderate & $9 \%$ & $11 \%$ & $9 \%$ & $11 \%$ & $11 \%$ & $29 \%$ & $34 \%$ & $29 \%$ & $9 \%$ & $17 \%$ \\
\hline Not Good & $11 \%$ & $17 \%$ & $29 \%$ & $23 \%$ & $20 \%$ & $3 \%$ & $29 \%$ & $20 \%$ & $14 \%$ & $18 \%$ \\
\hline Very Not Good & $40 \%$ & $43 \%$ & $37 \%$ & $51 \%$ & $34 \%$ & $20 \%$ & $3 \%$ & $29 \%$ & $49 \%$ & $34 \%$ \\
\hline \multicolumn{11}{|c|}{ Sabai Nan Aluih Nursing Home } \\
\hline Very Good & $2 \%$ & $2 \%$ & $2 \%$ & $2 \%$ & $0 \%$ & $2 \%$ & $0 \%$ & $2 \%$ & $7 \%$ & $2 \%$ \\
\hline Good & $42 \%$ & $22 \%$ & $33 \%$ & $31 \%$ & $24 \%$ & $27 \%$ & $13 \%$ & $13 \%$ & $29 \%$ & $26 \%$ \\
\hline Moderate & $18 \%$ & $22 \%$ & $16 \%$ & $20 \%$ & $31 \%$ & $51 \%$ & $49 \%$ & $31 \%$ & $20 \%$ & $29 \%$ \\
\hline Not Good & $27 \%$ & $42 \%$ & $33 \%$ & $27 \%$ & $9 \%$ & $4 \%$ & $16 \%$ & $7 \%$ & $9 \%$ & $19 \%$ \\
\hline Very Not Good & $11 \%$ & $11 \%$ & $16 \%$ & $20 \%$ & $36 \%$ & $16 \%$ & $22 \%$ & $47 \%$ & $36 \%$ & $24 \%$ \\
\hline
\end{tabular}

of everyday events, also known as sensorium memory; sensorium memory quickly disappears unless given attention to certain stimuli [13]. There are several stages of memory that are widely embraced, namely, formation, storage and recall of memory. Formation begins with stimuli from within and from outside. Stimulus from within, useful for maintaining basic life. For example, remembering time, thirst, and hunger or something else [14].

- Based on the researcher's analysis, the memory level of the elderly to remember the time or hour either because all activities held in the nursing home of Husnul Khotimah Pekanbaru and Sabai Nan Aluih Pariaman has been determined, such as breakfast and lunch schedules, sports activities, and predetermined artistic activities. So that, the elderly feel used to the scheduling where the elderly tries to always see the time or hour of the day.

\section{Aspects of motivation}

- Motivation is a condition in a person's personality that encourages individual desire to carry out certain activities to achieve a goal [15]. A person's motivation will manifest a behavior directed at the goal of achieving satisfaction goals. In broad outline, motivation can be divided into intrinsic and extrinsic motivation [16].

- Based on the researcher's analysis of the motivation of the elderly in the two nursing homes in the adequate category, in the Husnul
Khotimah nursing home, the management and family members feel indifferent to the condition of the elderly because the elderly are rarely visited by their families, including children, grandchildren, and relatives. At the Sabai Nan Aluih nursing home, the elderly must remember spirituality every day. Based on the religion of the respondents, the majority of respondents are Muslim, as many as 45 respondents $(100 \%)$. This is in line with the majority of Indonesia's population who are Muslim [17], [18]. According to the Hawari (2009) in [19] in Islam, there is a mental health dimension in the five pillars of Islam. Spiritual health can exist, both in people who are religious and people who are not religious according to the Fowler 1981 in Kozier [20].

\section{Aspects of independence}

The results of the study describing the level of independence of the elderly (60-69 years) in fulfilling daily living activities show that the most of the elderly as many as 15 people $(72 \%)$ are partially dependent, three people $(14 \%)$ are independent, and three people (14\%) are included in total dependence. That most of the elderly at the Tresna Wredha social home are partly dependent in carrying out their life activities. It is hoped that health programs for the elderly can be developed that can increase the independence of the elderly [20], [21].

Based on the researcher's analysis, the independence of the elderly was in a good

Table 4: The percentage of independence aspects of elderly between Husnul Khotimah nursing home and Sabai Nan Aluih nursing home

\begin{tabular}{|c|c|c|c|c|c|c|c|c|c|c|}
\hline Independence Aspects & Lavatory & $\begin{array}{l}\text { Taking } \\
\text { medicines }\end{array}$ & Conflicts & $\begin{array}{l}\text { Completing } \\
\text { tasks }\end{array}$ & Helping friends & $\begin{array}{l}\text { Putting things in } \\
\text { the right place }\end{array}$ & $\begin{array}{l}\text { bEing happy to } \\
\text { be involved }\end{array}$ & Perceptions & Assignment & Average \\
\hline \multicolumn{11}{|c|}{ Husnul Khotimah Nursing Home } \\
\hline Very Good & $23 \%$ & $34 \%$ & $17 \%$ & $26 \%$ & $17 \%$ & $14 \%$ & $11 \%$ & $6 \%$ & $9 \%$ & $17 \%$ \\
\hline Good & $29 \%$ & $54 \%$ & $66 \%$ & $60 \%$ & $69 \%$ & $74 \%$ & $71 \%$ & $80 \%$ & $71 \%$ & $64 \%$ \\
\hline Moderate & $6 \%$ & $3 \%$ & $11 \%$ & $14 \%$ & $6 \%$ & $6 \%$ & $14 \%$ & $6 \%$ & $9 \%$ & $8 \%$ \\
\hline Not Good & $3 \%$ & $0 \%$ & $3 \%$ & $0 \%$ & $9 \%$ & $3 \%$ & $3 \%$ & $9 \%$ & $11 \%$ & $4 \%$ \\
\hline Very Not Good & $40 \%$ & $9 \%$ & $3 \%$ & $0 \%$ & $0 \%$ & $3 \%$ & $0 \%$ & $0 \%$ & $0 \%$ & $6 \%$ \\
\hline \multicolumn{11}{|c|}{ Sabai Nan Aluih Nursing Home } \\
\hline Very Good & $18 \%$ & $20 \%$ & $9 \%$ & $9 \%$ & $7 \%$ & $9 \%$ & $2 \%$ & $4 \%$ & $4 \%$ & $9 \%$ \\
\hline Good & $56 \%$ & $51 \%$ & $51 \%$ & $64 \%$ & $51 \%$ & $64 \%$ & $67 \%$ & $64 \%$ & $58 \%$ & $59 \%$ \\
\hline Moderate & $7 \%$ & $9 \%$ & $20 \%$ & $11 \%$ & $29 \%$ & $18 \%$ & $16 \%$ & $20 \%$ & $24 \%$ & $17 \%$ \\
\hline Not Good & $11 \%$ & $2 \%$ & $11 \%$ & $4 \%$ & $0 \%$ & $7 \%$ & $9 \%$ & $4 \%$ & $9 \%$ & $6 \%$ \\
\hline Very Not Good & $9 \%$ & $18 \%$ & $9 \%$ & $11 \%$ & $13 \%$ & $2 \%$ & $7 \%$ & $7 \%$ & $4 \%$ & $9 \%$ \\
\hline
\end{tabular}


category when given the task of discussing and equating perceptions. It can be concluded that they are independent and some of the elderly still have a level of independence that depends on the manager in carrying out physical activities such as toilets due to poor health conditions, such as diseases that occur in the elderly in nursing homes, namely, strokes and psychological disorders due to the aging process and other diseases. At the Sabai Nan Aluih nursing home, the category is quite happy to be involved in the activities in the nursing home based on the analysis of the elderly researchers who are very happy with the activities held at the nursing home; this can reduce boredom and boredom in being active daily [22].

\section{Conclusion}

The conclusion that can be obtained from this study is the psychological condition of the elderly from the aspects of emotion, memory, good category motivation, good category motivation, and good category independence at the Husnul Khotimah nursing home and moderate at the Sabai Nan Aluih nursing home. This is because the factors of age and diseases experienced by the elderly such as hypertension, stroke, diabetes, and dementia, which are common in old age, are a decline in brain function experienced by the elderly.

\section{Thank You Note}

We would like to thank the head/staff of PSTW Husnul Khotimah Pekanbaru and PSTW Sabai Nan Aluih Sic Cincin Padang Pariaman, Chairperson of STIKes Hang Tuah Pekanbaru, respondents in this study who had provided various inputs/information, so that this article could be presented. The author would like to thank LPPM for funding this research through a Dissertation Scholarship which has provided moral and material support during the research implementation.

\section{References}

1. Kuntjorowati E. Comfortable and peaceful at budi dharma elderlyhome service. J Penelit Kesejaht Sos. 2018;16(2):209-22.
2. Badan Pusat Statistik. Perempuan dan Laki-Laki di Indonesia 2019. Jakarta: Badan Pusat Statistik; 2020

3. Festy P. Lanjut Usia Perspektif dan Masalah. Indonesia: Universitas Muhammadiyah Surabaya Publishing, 2018.

4. Luthfa I. Perbedaan kualitas hidup lansia yang tinggal bersama keluarga dengan lansia yang tinggal di rumah pelayanan sosial. J Wacana Kesehat. 2018;3(1):66.

5. Rodhiyah S. Perbedaan Kualitas Hidup Lansia Yang Tingga Bersama Keluarga Dengan Lansia Yang Tinggal Sendiri di Desa Sukorini Manisrenggo. Indonesia: STIKES Muhammadiyah Klaten; 2020.

6. Kiik SM, Sahar J, Permatasari H. Peningkatan kualitas hidup lanjut usia (lansia) di kota depok dengan latihan keseimbangan. J Keperawatan Indones. 2018;21(2):109-16.

7. Suardiman SP. Psikologis Usia Lanjut. Yogyakarta: Badan Penerbit dan Publikasi Universitas Gadjah Mada; 2011.

8. Andriyani W. Literature review: Faktor-faktor yang berhubungan dengan kemandirian lansia dalam melakukan activity daily living. Nurs Sci J. 2020;4(2):65-80.

9. Mahendra CA. Pengaruh Intermittent Fasting Terhadap Decision-making Pasca Paparan Stres Akut. Indonesia: Medical Faculty of Universitas Muhammadiyah Surakarta; 2019.

10. Tentama F. Hubungan positive thinking dengan self-acceptance pada difabel (bawaan lahir) di SLB negeri 3 Yogyakarta. J Psikol Integr. 2014;2(2):25.

11. Herawati W. Berpikir Positif Pada Lansia di Panti Jompo. Yogyakarta: Fakultas Psikologi Universitas Ahmad Dahlan; 2018.

12. Latour B. Science in Action: How to Follow Scientists and Engineers Through Society. United States: Harvard University Press; 1987.

13. Siregar S. Pembelajaran sistem ekskresi dengan metode mnemonik untuk meningkatkan retensi (daya ingat) dan hasil belajar siswa. Serambi Konstr. 2020;2(1):2190.

14. Duzel E, van Praag $H$, Sendtner $M$. Can physical exercise in old age improve memory and hippocampal function? Brain. 2016;139(3):662-73. https://doi.org/10.1093/brain/awv407 PMid:26912638

15. Aprilia SM. Motivasi Hidup Pada Lansia di Panti Werdha. Fak Psikol Univ Ahmad Dahlan. Yogyakarata: Fakultas Psikologi Universitas Ahmad Dahlan; 2018.

16. Ghufron MN, Risnawita R. Teori-teori psikologi. Yogyakarta: Arruz Media. Handayani, SriWiroro Retno Indah dan Suharman. 2012. Konsep Diri, stress, dan prokrastinasi akademik pada Mahasiswa. J Psikol Indones. 2010;1(2):36.

17. Cahyani RD. Hubungan Spiritualitas Dengan Stres Pada Lansia di UPT Pelayanan Sosial Tresna Werdha (PSTW) JEMBER. Indonesia: Universitas Muhammadiyah Jember; 2018.

18. Khairani K. Spiritualitas lanjut usia di panti sosial. J IIm Mhs Fak Keperawatan. 2018;3(3):1-8.

19. Hawari D. Dimensi Kesehatan Jiwa Dalam Rukun Iman Dan Rukun Islam. Jakarta: Fakultas Kedokteran Universitas Indonesia; 2009.

20. Berman A, Snyder S, Frandsen G. Kozier and Erb's Fundamentals of Nursing. $4^{\text {th }}$ ed. Australia: Pearson Australia; 2018.

21. Aminuddin $M$, Kapriliansyah $M$, Nopriyanto $D$. The level of independence of the elderly in the activity of daily living (ADL) at tresna werdha nirwarna puri samarinda social home using the barthel index method. J Kesehat Pasak Bumi Kalimantan. 2020;3(1):14-20.

22. Herman R, Akhriani HN. Determinants activity of daily living (ADL) elderly tresna werdha nursing home (PSTW) special region of Yogyakarta. Jump Health. 2018;2(1):81-92. 